\title{
Drawing on the Legal and Economic Arguments in Favour and Against 'Reciprocity' and 'Special and Differential Treatment' for Developing Countries within the WTO System
}

\author{
Maria Luiza Kurban Jobim ${ }^{1}$ \\ ${ }^{1}$ Faculty of Law, University of Kent, Canterbury, UK \\ Correspondence: Maria Luiza Kurban Jobim, Faculty of Law, Universidade Federal do Rio Grande do Sul \\ (UFRGS), Porto Alegre, Brazil. E-mail: marialuiza_jobim@yahoo.com; luizajobim@gmail.com
}

Received: March 15, 2013 Accepted: April 17, 2013 Online Published: August 30, 2013

doi:10.5539/jpl.v6n3p55 URL: http://dx.doi.org/10.5539/jpl.v6n3p55

\begin{abstract}
The international trade regime embodied in the World Trade Organization (WTO) goes beyond a collection of texts and agreements. As legal rules are not immune to political and economical influences, they have to be analysed in the context in which they have been created and constantly modified. Nowadays, the multilateral system of the WTO gains complexity when the market place does not restrict its subject to goods anymore and when the goal of development is materialized, in its agreements, as one of the pillars of the WTO. Developing countries, empowered by the launch of their economic growth, are acquiring space and voice to criticize the legal framework of the WTO, saying it has not been entirely coherent with its own objectives and claiming for the adoption of an effective Special and Differential Treatment (SDT). On the other hand, developed countries, based on their economic superiority and underlining the importance of free trade through liberalization policies, insist on the necessity of reciprocal commitments to promote economic growth and global welfare. This dilemma is traduced in the impasse of the recent Doha Round, but it is already time for more ideas to be brought and paradoxes to be resolved. The current challenge faced in this study becomes then to conciliate the SDT, Reciprocity the development concerns. At the end, preferential systems do not go against liberalization. Instead, the SDT intends to graduate the liberalization process through fairness (development) and to enable, only afterwards, that seriously discussions regarding free trade and Reciprocity can be held regarding their full or, more plausibly, partial implementation.
\end{abstract}

Keywords: WTO, reciprocity, Special and Differential Treatment, developing countries

\section{Introduction}

The notion that trade - free trade, unencumbered by government restrictions is welfare enhancing is one of the most fundamental doctrines in modern economics, dating back at least to Adam Smith (1776) and David Ricardo (1816). But the subject has always been mark by controversy because the issue facing most countries is not a binary choice of autarky (no trade) or free trade, but rather a choice among a spectrum of trade regimes with varying degrees of liberalization (Stiglitz \& Charlton, 2005, 12).

The international trade regime embodied in the World Trade Organization (WTO) goes beyond a collection of texts and agreements. As legal rules are not immune to political and economical influences, they have to be analysed in the context in which they have been created and constantly modified. The legal support is a dynamic instrument aiming both to address and to correct imbalances. However, in a multilateral system such as the WTO, regulation transcends the classic concern of benefits to the direct parties involved in a particular agreement to assure its compliance according to development concerns. (Alessandrini, 2011, 168).

The economic exchanges in the market place are no longer restricted to goods. That is to say, complexities and paradoxes of the WTO legal system have been improved significantly over the last few decades. Developing countries, empowered by the launch of their economic growth, are acquiring space and voice to criticize the legal framework of the WTO, saying it has not been entirely coherent with its own objectives and claiming for the adoption of an effective Special and Differential Treatment (SDT) (WTO Doc WT/GC/W/442 2001). On the other 
hand, developed countries, based on their economic superiority and underlining the importance of free trade through liberalization policies, insist on the necessity of reciprocal commitments to promote economic growth and global welfare. The question is, then, on what grounds liberalization processes should be observed within a world increasingly interdependent and interconnected (Alavi, 2009).

Faced with this dilemma, the present study outlines the main objections and arguments regarding the SDT and the Reciprocity principle in accordance to the WTO framework, taking into account developing countries current position and interests. The starting point is to analyse the path of the worldwide trading system since the middle of the last century, the economic and political arguments that led to the GATT 1947 and its core features, which remain the basis of the current trade regime. Then, addressing the specific situations of developing countries and their empowerment, the study conceptualizes the SDT in the international scenario through the dimensions of (i) non-reciprocity; (ii) permissive protection, (iii) systems of preferences - in order to verify whether positives results were obtained - and also, (iv) what those outcomes might indicate. Finally, focusing on the conception and on the design of the WTO since the Uruguay Round, it is examined the questioned efficiency of the practice of reciprocity in negotiations with developing countries. At the end, the issue does not relate to the adoption or not of reciprocal and differential treatment, but, rather, explains the SDT meaning in order to answer whether they can efficiently assist developing countries to benefit from trade in the pursuit of development.

\section{Nature and Character of GATT: The Pursuit of Free Trade}

The purpose of this paper cannot be analysed without a prior understanding of the economic and political events that contributed to the international trade regime which has been designed since the middle of the last century. From the Great Depression of 1929 until the 1940s, the United States (US) and the United Kingdom (UK) were the main actors engaged in designing a new world order which would define the post-World War II period. The economic aspects of the new order were based on the common ideological liberalism of free trade to fight against the Soviet 'threat' (Alavi, 2009: 74). In 1944, the US hosted a multilateral and binding conference, the 'UN Monetary and Financial Conference' also known as the Bretton Woods Conference. The intention was to strengthen international cooperation between countries by coordinating policies and actions against protectionisms in order to achieve economic growth. This first Conference resulted in the creation of the International Monetary Fund (IMF), in the institution of the World Bank and in the foundation of the International Trade Organization (ITO) (Trebilcock \& Howse, 2005: 23).

After the World War II, Europe needed to be reconstructed and the US remained as the main force promoting the establishment of an international trade regime, partly due to its own interest in opening markets. During the years of 1946 and 1948, four UN conferences were held to discuss tariffs reduction on almost 45000 goods for twenty three countries. The results were then embodied in the General Agreement in Tariffs and Trade (GATT, 1947), which originally was supposed to be an interim multilateral treaty and a part of the ITO. The fourth UN conference, the Havana Conference, in 1948, testified the collapse of the ITO and consequently, the GATT became the facto regulatory framework for the international trade (Trebilcock \& Howse, 2005: 23).

Notwithstanding the logic of the multilateral negotiations, the GATT initial provisions reflected mainly the US position (Alavi, 2009: 79), with emphasis in the pursuit of free trade through the process of lowering barriers. The basic principle of the GATT is the Non-discrimination, which presents two dimensions: (i) the Most Favoured Nation (MFT): that requires equal treatment between countries (art. I.1, GATT 1947) and (ii) the National Treatment (NT): that requires equal treatment between and within countries (art. III GATT, 1947). Conversely, there were also exceptions of this rule, especially regarding agriculture and textile products, the protection of internal industry (enabled with the idea of infant industries), among other hypotheses (Carl, 2001: 78).

In this manner, despite the MFN clause presence in Article I, its own Paragraph 2 permitted the continuation of existing trade preferences between colonial powers and their former dependencies. The provision thereof addressed the conflict between the US and the European approaches regarding the desired features of the trade regime in construction at that time. Therefore, the General Preference System (GPS) could be seen as a mechanism of developing countries' differentiation according to developed countries' strategies. Europe took advantage of this differential treatment with their ex-colonies to maximize its gains by controlling trade and suppressing economic competition in those regions (Dunoff, 2009: 48) - maintaining, in this manner, their historical systems of preferences for colonial areas - while the US sought a non-discriminatory system that had no special rules to developing countries (Deese, 2008: 17). Both positions reflected national interests, and, as a result, the text contained paradoxes: it provided for developing states the protection of the infant industry and the allowance to obtain specific balance of payment results, although not the preferential access to developed states markets that those states sought. 
Hence, as a central pillar of this regime and under the unconditional MFN clause, there was the role of Reciprocity, which run throughout the system and briefly meant that tariff negotiations should be conducted on a reciprocal and mutually advantageous basis (GATT, 1947, Article, XXVIII). There are found four reasons behind the rule: (i) to avoid "free riders" (Carl, 2001: 79); (ii) to satisfy a country's domestic sceptics; (iii) to be a bargaining chip in negotiations with other countries and (iv) to encourage countries do reduce their trade barriers (Alavi, 2009: 82).

However, as the GATT was supposed to work together with the ITO and the latter was never established, there were some gaps in its structure which include 'its provisional nature, the lack of any organization to support it, its vague and somehow incomplete rules, and its many exceptions to the general rules' (Alavi, 2009: 77). Hence, the GATT was visibly a broad agreement with the scope to remove barriers to trade, but due to the lack of a sufficiently rule-oriented organization, negotiations were mainly driven by diplomatic, political and economic relations.

\section{Acknowledging Differences and Imbalances: The Creation of the Special and Differential Treatment (SDT) to Developing Countries}

During the original Bretton Woods negotiations (Trebilcock \& Howse, 2005: 470) developing countries would have a marginal influence and participation on the design of the international trade which was being designed therein. In the following decades of 1960s and 1970s, incipient economic gains enabled those countries to acquire a significant share of the world trade and to pressure to receive a more preferential treatment within the GATT. As a result, the idea of a Special and Differential Treatment (SDT) was introduced in the system. It initially expressed that poor countries would be exempted from making reciprocal concessions in trading negotiations (Thomas \& Trachtman, 2009: 4). However, the concept actually embraces a wider idea. The SDT can be dogmatically analysed by three distinguished angles: non-reciprocity, permissive protection and general preference of systems, which are the focuses of the present chapter. The distinction is essential to verify the eventual efficiency of these mechanisms in practical terms to development purposes.

\subsection{Non-reciprocity}

The 'non-reciprocity' principle is addressed in the Part IV of the GATT, specifically in the Article XXXVI, which provides that contracting parties cannot not expect reciprocity from less-developing parties in negotiations regarding the reduction or the removal of tariffs. The idea is complemented by the Article XXXVII, which imposes to rich countries the assumption of non binding obligations to the fullest extent possible and the reduction or elimination of obstacles regarding the products of interest to developing countries. The vagueness of the non-reciprocity principle and the lack of its transplantation into legal commitments testify the obstacles faced by developing countries to achieve positive outcomes in the pragmatic field. That is to say, the reality of negotiations showed that developed countries would not have the willingness to negotiate with developing countries when their potential concessions were not expected to provide them reciprocal benefits (Alessandrini, 2011: 174-176).

\subsection{Permissive Protection: Import Substitution and Infant industry}

The protection allowance for developing countries is retained under the Articles XI, XII, XII and XVIII of the GATT. The most visible recognition of the differential treatment to developing countries can be found in the Article XVIII, extending them the possibility of: (a) maintaining sufficient flexibility in their tariff structure in order to enable the establishment of a particular industry and (b) applying quantitative restrictions for achieving equilibrium in their balance of payments scheme. This legal provision enabled a number of developing countries to grant significant exemptions from the GATT strictures, such as import substitution policies and infant industries protection.

The import substitution policy was used by a number of Latin American countries after the Second World War (Trebilcock \& Howse, 2005: 474). These countries were considerably inspired by the 'big bang' of the Stalinist industrialization during the 1930s and the Soviet Union rapid capital growth rates, while the more liberal Western capitalist economies were floundered in the Great Depression. Since the developing countries' production consisted mainly of agricultural goods, the economic growth was pursued in the industrialization process. The main idea was to substitute manufactured goods imports by national fabrication. For that to occur, it was necessary to encourage domestic industries to flourish with governmental programmes of incentives while restricting substantially the entrance of foreign products. It was argued that only 'essential' capital goods should be imported. In Brazil, during the year of 1951, Getulio Vargas established a system of import licensing to give priority of fuel and capital goods, accompanied by an increased protection for domestically produced goods in the following years. In the 1950s, 1960s and 1970s similar import substitutions were pursued by developing countries across the world including Chile, Peru, Mexico, Argentina, and others (Stiglitz \& Charlton, 2005, 19). The era of the 1970s in Brazil was then defined as the 'Brazilian miracle', due to the surreal wealth proportioned by this policy (Rodrik, 2011, xvii). 
According to Stiglitz and Charlton "the practice was obviously the "anathema" of the theory of comparative advantage defended by David Ricardo [once t] he comparative advantage was thereby seen as some benefit that should be constructed and promoted by state intervention.' (Stiglitz \& Charlton, 2005, 19). The intersection of economy and politics were then clearly observed, but the results were disappointing. Notwithstanding Latin American countries growth during the decades of the import substitution schemes, their policies were highly dependent on foreign capital, evidenced by their high share of flows of Foreign Direct Investments (FDI), what turned these countries particularly vulnerable to global economic shocks (Stiglitz \& Charlton, 2005: 22). As 'miracles' do not exist, the growth was actually constructed upon heavy borrows from international institutions such as the World Bank and the International Monetary Fund (IMF) during this period. (Rodrik, 2011, xvii). In the 1980s, the majority of Latin American countries would find themselves in difficulties caused by this debt policy, exacerbated by unfortunate global circumstances, specifically, the oil crisis (Chang, 2011, xvii).

Conversely, the East Asian Tiger success can be attributed to different measures taken by governmental policies. Despite the formal appearance, import substitution policies in Latin America were far more open than the South East Asian protection of their infant industry, where controls over foreign capital were strict and thereby reliance on market forces 'did not preclude and active role for the government, including interventionist policies in trade, technology transfer, and domestic resource allocation.' (Stiglitz \& Charlton, 2005: 89). The contrast of the results achieved by East Asia led to the disbelief in import substitution policies and was a threshold for plenty structural modifications in many of the developing countries internal policies to start (Trebilcock \& Howse, 2005: 489).

\subsection{General Preference of Systems (GSP): Achievements and Limitations}

Nevertheless, the most visible formal results in the SDT relates to the Generalized System of Preferences (GSP). Initially, the GSP was designed upon the auspices of the United Nations Conference on Trade and Development (UNCTAD, 1971) and it incorporated the possibility of different treatments among developing countries, according to their development stages. Even though the initial intention was for developed countries to grant preferences to their ex-colonies, the GSP scope has been considerably amplified. For the GSP to be operative, a waiver pursuant to Article XXV of the GATT was created in 1971 in order to mitigate the content of the MFN clause of the Article I and thereby to permit the implementation of a preferential system within the international trade regime. In 1979, the rule of preferences was definitely established in a permanent basis with the introduction of the Enabling Clause (WTO, L/4903 1979).

However, the Enabling Clause has given developed countries wide and discretionary powers to manage and to construct their own systems of preferences (Trebilcock \& Howse, 2005: 477). Developed countries could select the products they would like to import, and the incentives were usually focused on primary-product industries, what provided 'perverse incentives against manufacturing in poor countries.' (Thomas \& Trachtman, 2009: 6; Trebilcock \& Howse, 2005: 481). Often, the system only confirmed the comparative advantage of determined countries which had already presented the conditions to succeed in export markets, namely the Newly Industrializing Countries (NIC). Consequently, the system has only testified its own inefficiency in terms of stimulating new actors to engage in the international trade regime.

Additionally, when differential treatment was given, Europe and the US used to impose numerous conditions to its accession, while adopting a questionable 'graduation policy', which was built, uniquely, according to their needs. As a result, preferences were seen as a temporary benefit that could be removed at any time depending on the criterions adopted by a determined country and on the interpretation given to their own scheme. This instability hindered developing countries and their respective industries to form a 'solid basis for investment' and thereby limited their long-term growth (Trebilcock \& Howse, 2005: 481).

Generally speaking, the market access in sectors such as textiles, manufactures, agriculture and tropical products, sectors of interest of developing countries, remained obscured thanks to the constant tariff peaks and escalation (Trebilcock \& Howse, 2005, 481). It is true that the GSP have been quite ineffective and have not done much to assist export growth in the developing world. One of the drawbacks of these non-binding trade preferences was that it leaded an 'open door' to explicit discrimination between developing countries (WTO, WT/DS246/4, 2002). The general rule of non-reciprocity was contrasted in practice by the constant threat of withdrawing the GSP status to states that could try to deny compliance with their requirements. The system was used both as a political and as an economic weapon. The mercantilist practice was still evident by the conditionality of the preferences offered by developed countries. From this spectre, it was clear that liberalization was usually a condition imposed by those powerful countries. For instance, the US Trade Act of 1974 gave the US President authority to waive GSP status if the country in question failed to provide 'reasonable access' to its markets and to its commodities' and if it did not afford 'adequate' and effective protection of intellectual propriety rights (Trebilcock \& Howse, 2005: 481). Thus, 
the collapse of the GSP testifies the strength of original principles of the international trade regime based on the Reciprocity and on the need to liberalize (Moore, 1992; Harvey, 2005: 29).

\subsection{A General Overview: Advantages and Disadvantages of SDT}

Undoubtedly, the GSP has promoted modest benefits to developing countries, but the SDT is not reduced to it. Arguments against the adoption of preferences are also wider than the motives just exposed herein regarding the inadequacy of the GSP. Rapid liberalization advocates point out that the allowance to emerging economies to pursue their own interests through development policies entail negative externalities to other developing countries (Stiglitz \& Charlton, 2008: 13). There is also the argument that the SDT leads to protectionist trade policies which are inefficient tools for industrial development in terms of creating vested interests and of misallocating resources. These advocates believe that even if the government had the willingness to subsidize national industries, it would face several obstacles to 'pick the right winners' (Trubek \& Cottrel, 2009). Consequently, 'granting exemptions to WTO disciplines, members would be doing a disservice to developing countries by encouraging protection, prolonging their exclusion from the global economy, and denying access to the benefits of openness' (Stiglitz \& Charlton, 2005: 88). Thus far, all these assumptions seem to neglect substantial differences among countries while the benefits of full liberalization are seen as easily achievable.

In fact, it is well known that trade policies of welfare maximization in rich countries might often conflict with the developing countries' aims. Developing countries are not a homogeneous group. For instance, due to their diversified economies and realities, the group known nowadays as the G-20 (DDA, 2003), that includes, among other countries, Brazil, Pakistan and China, might present diametrical opposed interests. Surely, the adoption of a more favourable measure to one state could imply a harmful effect to the other, but so as the many measures that are being taken in the international trade regime in disregard of development concerns. When some developing countries might be affected by preferential instruments available to other members, the answer might be found in coordination between international and national policies (Rodrik, 2011, xviii). Actually, there is an important role for developing states to play in their international policy, by encompassing their actions through coalitions, for example (Narlikar, 2006) and in their domestic policy, in order to enable them to compete in the international market while diminishing their vulnerability. As already outlined by Hudec (Hudec, 1987), emerging economies shall not have their sovereignty constrained. There were provisions that included balance of payments measures (Article XVIII, GATT, 1947), support to help developing countries to pay the costs of effectively participating in the WTO, aid to increase developing countries' capacity to take advantage of new trade opportunities, exemptions from agreements (which allow developing countries to choose whether or not to implement agreements requiring regulatory or administrative reform) and provisions allowing developed countries to give preferential market access to developing countries members (Stiglitz \& Charlton, 2005: 88). Accordingly, due to these failures pointed above regarding differential systems designed until these days, the idea surrounding the SDT was considerably reshaped after the 1970s.

\section{The "Shift" to Reciprocity and Developing Countries: Challenges, Trading Practices and Implications to the Present WTO System}

After developing countries' inclusion in the GATT in 1948, the so called "less developed countries" (like Brazil, Burma, China, Ceylon, Chile Cuba, Czechoslovakia, India, Lebanon, Pakistan, etc out of which many withdrew a few years later and among many developing countries in the current classification) argued that universal rules of trade did not take into account their specific concerns. As a result, as Donatella Alessandrini suggests, GATT article XVIII provided for some measures of protection, namely quantitative restrictions. But, besides being to be carried over art 13 of the never ratified ITO Charter, these measures were to be subject to the prior expert scrutiny and to the approval of the contracting parties - and with the exception of Ceylon, Cuba, Haiti and India, less developed countries never relied on this complex article (Alessandrini, 2011: 55). Afterwards, during the Tokyo round, in 1978, the informal group of developing countries included more than 55 countries - and was the leading force that advocated for the adoption of the subsidies and of the anti-dumping code (Steinberg, 2002).

However, given the unsatisfactory results of many schemes of the SDT, which lead to the crisis of the 1980s, developed countries pointed out the inefficiency of those systems and the need to restore the principle of Reciprocity. Simultaneously, the lack of a stable and sufficient coalition (Alessandrini, 2009) between developing countries in the international scenario intensified the necessity of a worldwide organization not only to update many of the trading rules which did not accomplish the transformations in the global economy, but also to provide enforcement mechanisms to those norms (Alavi, 2009: 5). That was the moment of the WTO creation. (WTO, Marrakesh Agreement, 1994). 
In this sense, Reciprocity was conceived within this new design of the trading regime to become an efficient tool to be used by developing countries in negotiations. The idea was to enable these countries to call for further commitments from the developed world on a mandatory basis. Emerging economies would then move from 'non-paying participants' (Chimni, 2009: 22) in unilateral preferential schemes, which proved to be inept, towards a 'rules-based multilateral system' endowed with an effective enforcement mechanism (Alessandrini, 2009). Conversely, the SDT has been considerably weaken by the spread of hortatory provisions and by the idea of being the exception - not the rule - to give to developing countries transition periods to adapt themselves to general commitments and technical assistance to enable their respective compliance. Out of almost 145 special and differential treatment provisions still observed within the Uruguay Round, few of them are legally enforceable because they only involve a best-efforts promise (Trebilcock \& Howse, 2011: 174). This fact reveals the weakness of this framework and, subsequently, the ineffectiveness of the SDT to respond to the needs of developing countries in the current era.

Furthermore, departing from a vague and questionable idea of isonomy, countries need to achieve a consensus (Articles IX and X, WTO, Marrakesh Agreement, 1994) in order for agreements to be signed. That is because, since the Uruguay Round, the WTO negotiations endorse the 'Single Undertaking Approach' (SUA), also defined as 'an all or nothing package' (Steger, 2007: 483), designed to bring uniformity of commitments between member states, so all of them become abided by the same rules. In other words, the Single Undertaking Approach means that nothing would be agreed upon until everything on the negotiating table is ultimately accepted by all contracting parties (Alesssandrini, 2009). Equal treatment is seen as a requisite which undeniably would lead to development. But, as Chang has already pointed out, 'when we look at the detail we realize that the field is not level at all' (Chang, 2008: 75). That is to say, differences not only remain between contracting parties themselves, but also in the extent of commitments in practice each one of them can possibly observe and comply.

Actually, the simple adoption of the free trade argument embedded in the present neoliberal theories neglects different levels of development and of bargaining power between states, elements which have crucial influence in the negotiation process. It is thus hard to believe that reciprocal commitments would provide gains for all the members in the same proportion. Chang addresses the fact that even though the rich countries have low average protection, they tend to disproportionately protect products that poor countries export, especially garments and textiles. He then brings the example of India that, in 2002, paid more tariffs to the US government than Britain, despite the fact that the size of its economy was less than one-third that of the UK. (Chang, 2008: 75).

That is to say, the idea of focusing, solely, on the enforcement of 'agreed' obligations assume, wrongly, their fairness. It is well known the important role performed by international politics in the approval process of international agreements and its content (Chimni, 2009: 30): the purpose is to give prominence to the role of the (free) market over domestic policies in order to promote development (Ismail, 2012), despite the visible failures attached to this approach.

The market framework that is designed solely in the pursuit of economic gains does not necessarily lead to development; it will have to be made so. Additionally, the WTO negotiations are made among states representing their 'national self interests' of profit maximization that, not rarely, go against development policies (Dunoff, 2009). Liberalization process involves externalities which are actually 'internalities' of the adoption of free trade theories that cannot be explained simply by theories of comparative advantage. Opening the market completely can be disastrous to developing economies (in terms of labour dislocation and unemployment for example), especially considering industries which are not yet prepared to compete vigorously in the international scenario (Trebilcock \& Howse, 2005: 491).

Some countries might face numerous obstacles when trying to construct their comparative advantage in another sector, specially the poorest ones (Griffin, 1978: 22). There are also the problems faced by some of the so called least-developed countries (LDC) which are highly dependent on tariff revenues to elaborate their social programmes of adjustment. With the full liberalization not only does the state have a significant loss, but also the nationals who are not able to be supported by government expenditure. Briefly, several reasons can be appointed for this inability to resources relocation: firstly, the natural resources limitation; secondly, the widespread of illiteracy in poor education systems and thirdly the capital immobility. According to Griffin (Griffin, 1978: 22), the mobility of capital largely depends on the rate of investment. So, 'the greater the additions to the stock of capital, the easier is to alter the composition of the stock of capital. (...) Growth provides flexibility and enables a country to respond quickly to changing opportunities. Thus the rich, rapidly expanding countries are able to benefit from the opportunity of trade, while the poor, slowly growing countries are not, or at least not to the same extent.' Consequently, there are cases, where the potential benefits of free international trade can be easily lost. 
Differently from the GATT 1947 (GATT, 1947, preamble) which was conceived in the middle of the last century, the WTO has explicitly broader goals (WTO, 1994, preamble). While the former use to prioritize explicitly the pursuit of trade liberalization in order to promote economic growth, the later has the commitment to encourage wealth and prosperity together with environmental sustainability and development, as perceived by the following excerpt:

.. Recognizing that their relations in the field of trade and economic endeavour should be conducted with a view to raising standards of living (...) with the objective of sustainable development, seeking both to protect and preserve the environment and to enhance the means for doing so in a manner consistent with their respective needs and concerns at different levels of economic development... (added emphasis).

The structure of international trade regime has been largely modified since its original conception in 1947, especially regarding the contracting parties. Developing countries are a majority within the WTO system, including the so called emerging powers like China, Brazil and India. The transformation from a bi-polar trading system driven by the US and Europe to a multi-polar one means that the rich countries cannot drive the negotiations as they used to do during the old days (Steger, 2007: 483).

For instance, a well-known coalition known as the G-77, more China detected, in their Declaration (WTO, 2001), great obstacles of the SDT application, outlined below:

7. We believe that since the Special and Differential (S\&D) provisions in the existing UR agreements, are mostly in form and not in substance, WTO Agreements should take into account the special development needs of developing countries, including LDCs, in a more meaningful and effective manner and call upon developed countries to urgently undertake positive measures to respond to the development, financial and trade needs of developing countries without reciprocal obligations. It also needs to ensure their effective applicability in terms of the intended objectives, by making those provisions more precise and effective. These provisions need to be legally binding and must be operationalised and made enforceable so that these do not remain merely "best endeavour clauses." The members should agree to conclude a Framework Agreement on the S\&D Provisions.

That is to say, the approach to Reciprocity outlined above still evidences the mercantilist view of the international trade (Hudec, 1987: 142). Developing countries, in order receive 'concessions' regarding market access in developed economies, were expected to lower their trade barriers as well (Dunoff, 2009: 42). Considering the current framework of the WTO and its negotiations, that goes beyond the traditional regulation of trade in goods (which includes services, intellectual property rights, agriculture, investments) and the constant resistance of rich countries to liberalize sectors which are of interest of developing countries (Deese, 2008: 19), the less developed ones are often required to make trade-offs 'as a quid pro quo for the elimination of the discrimination against their trade', what might be quite harmful to their real development (Alessandrini, 2009). To illustrate the situation, Chang comments the current bargain on the Doha round between NAMA (non-agriculture market access) and agriculture. The mutual concessions are being constructed upon a conditional offer: if developing countries cut off their industrial tariffs, their trading partners (rich countries) are about to lower their agriculture tariffs and subsidies in response (Chang, 2008: 78). However, even if that conditionality was real, which is not - once the negotiations in the field are better explained by a power rule based decision than by any simple bargaining operation (Steinberg, 2002) - development cannot be seen simply as an equivalent of economic growth. Furthermore, this comprehension is quite naive and underlines the old-fashioned mercantilist thought still persistent in these days that associates positive results in the balance of payment system with economic growth.

Hunter outlines that 'there is a growing sense that by accepting the outcome of Uruguay Round, developing countries paid a very high price for the promise of liberalization of the agricultural and textile sectors in the North - a promise most developing countries now consider broken.' (Hunter, 2009: 299). In this manner, the current trade-offs between diverse agreements, driven by an artificial idea of reciprocity, are getting development priorities wrong. Firstly, because developing countries are not a homogeneous group and do not have the same interests. For example, a concession of lowering barriers in agriculture might be quite beneficial to a country like Brazil, but may be quite harmful to another like Bangladesh (Trebilcock \& Howse, 2005: 493). Secondly, because inequality within countries is high and externalities, if present, might affect more the least well-off people in national standards (Chang, 2008; Griffin, 1978). Thirdly, and the most important, because usually the poor countries' concessions would not overcome the advantages they can obtain, once their resources are limited. As Chang explains regarding the trade-offs, even 'if agricultural liberalization by the rich countries can only be "bought" by developing countries giving up their use of the tools of infant industry promotion, the price is not 
worth paying (Chang, 2009: 80).' He thus concludes that developing countries should not be forced to sell their future for small immediate gains. In this manner, to believe in the existence of Reciprocity in a multilateral trading system is visible misleading.

Moreover, in the current WTO system, there are number of exemptions for the principle of Reciprocity, especially in areas of interest of developed countries: a) agricultural and research and development (R\&D) subsidies; b) enforcement of intellectual property rights; c) services liberalization, and d) the TRIMS (Trade-related-Investment Measures). Even though there are many TRIMS provisions yet to be decided under the Doha Round, many of them threatens to restrict the WTO member's sovereignty in terms of regulating foreign investments (TRIMS, article 9; Piccioto, 1998: 739). However, the Latin American crisis of the 1980s has already shown the consequences of rapid growth based upon foreign capital to domestic economies which are still too vulnerable to external events. Given the present era of the 'financialization' (Krippner, 2005: 173) of the economy, the acceptance of investments liberalization can be seen as 'more than full reciprocity' (Chimni, 2009: 33) because if countries have no sovereignty, it means they have no bargaining power to pursue concessions and to protect themselves against further commitments; hence, the results over developmental policies might be disastrous. And the control over a country's currency and foreign investment regulation by an international organization in disregard of national and domestic interests could be, in the view of Chang, 'far more dangerous than the use of military power' (Chang, 2008: 93).

For instance, due to the instability of the global economy after the US financial crisis, Brazil has been seen as an attractive option to invest, given the interest rates usually practiced by its Central Bank (Economist, 2009; Lundberg, 2010). On the October of 2010, the Brazilian government adopted a drastic measure with the announcement of two per cent taxation in the name of 'Tax on Financial Operations' (not included the FDI), as the result of a strong increment in the inflow of foreign capital, fixed or variable, in the country. According to Brazilian government, at that time, the objective was to avert an excessive speculation in the stock market (avoiding excessive real appreciation), to protect domestic production and to prevent unemployment. The concern about the Brazilian balance of payment was clear, at that time, in the speech of the Brazilian Treasury Minister, Guido Mantega: 'When the Real value goes up, the exports become more expensive, the imports become cheaper and our exportation rate does not increase as it should.' (Mantega, 2009).

However, the Brazilian taxation policies that have been adopted since then, aimed at stimulating the internal and industrial growth, have been quite polemical, not only internally (Costa \& Turolla, 2013) but also externally (Leahy, 2013; Rathborne, 2013). Even though the TRIMS' provisions are yet to be sufficiently designed and limited, a liberalizing view over the Brazilian unilateral act could be reproved taking into account the role of the Non-discrimination and of the National Treatment (NT) principles, for example (Piccioto, 1998: 731). Still, despite the questionable results obtained with this measure, in reality, after a couple of years, Brazilian arguments could have been sounded quite reasonable considering Brazilian internal policy (which has been adopted since the mid 1990s regarding financial regulation and the downturn suffered by their national industry) and considering the national concerns with long term growth (Economist, 2009; Lundberg, 2010: 43).

It shall be noted that the present argument regarding foreign investment does not mean that they should be banned or that they are always harmful (Evans, 1979). The discussed herein regard to the potential sovereignty limitationa restriction which is undesired. In fact, the benefits of foreign investment in the Brazilian industrialization process have been critically analysed by Evans. The author pointed out that foreign capital has helped to build an increasingly diversified industrial capacity in Brazil with implications in the social and in the economic life. In this manner, foreign investments were no longer an external force whose interests were represented internally by 'compradores' (buyers) and agrarian exporters. Instead, foreign capital, both private and state-controlled, would have an interest in the further development of local industry. To what extent these anecdotal evidences can be used as proxies or other similar situations in the future is hard to say. But, surely, that is a subject that governments should be free to decide.

The situation above exemplifies the complexity of contextualizing factual situations with the principles and exceptions which shall apply according to the WTO system in the current days (Alavi, 2009: 3). In fact, there is a massive critique of the indeterminacy which permeates the whole WTO framework. In the pragmatic field, the obscurity of rules allows the existence of conflicting interpretations and so the WTO bodies are demanded to choose the most appropriate one which, usually, is the one supported by the most powerful trading nations (Chimni, 2009: 32). Despite the existence of a Dispute Settlement Body (DSB) enacted in order to turn the rules effective, the WTO itself recognizes its weaknesses in resolving all the cases brought until now and acknowledges the complexity of the system (WTO, Settling disputes). In this scenario, Reciprocity should be constantly re-constructed and re-contextualized. It is then clear the intersection of legal, economical and political forces in the 
international trading regime. Rather, it is clear - at the moment, the submission of legal provisions to economic purposes through political mechanisms.

The old system of preferences is substituted by the multilateralism enacted by the principle of the MFN, which supposedly would be advantageous for all members (Hudec, 1987). Nevertheless, the impasses presented in the Doha Round do not seem positive to any contracting party and stimulate agreements to be signed between countries outside the international trade regime (Chimni, 2009). Impasses are mainly caused by the unwillingness of many developing countries to accept binding and enforceable commitments which do not address their special situation of economic development.

While States are still guided solely by their own self interests, and international trade is only seen as an instantaneous tool to promote economic gains, the Doha round standstill is likely to remain. The effectiveness of the WTO system is seriously in danger if there is not a shift on the 'culture' (Steger, 2007) of the trading regime which acknowledges not only in theory, but also in practice, the pursuit of development that consists in $n$ dimensions of human welfare, from the satisfaction of basic needs to the effective participation in society (Thorbecke, 2006).

It is then the whole idea of development that has been designed and constructed over time. For instance, at the beginning, during the 1950s and the 1960s, development was comprehended mainly in terms of economic expression and largely centred on the GNP growth. The belief and reliance on state intervention was a consequence of the discontinuous process of growth that allegedly less developed countries would have to face, largely inspired by the Soviet Union success (Stiglitz \& Charlton, 2005: 18). At that time, the main task aimed by developing theories was to promote the independence of less developed countries from their ex colonial powers through the design of appropriate policies and strategies that included import substitution mechanisms, infrastructure investments and concerns with employment within the idea of industrialization (Thorbecke, 2006). However, in the following decades, the failure of inward looking approaches was evidenced by high indexes of unemployment, inequality and by the rise of foreign indebtedness. That was the time when, during the 1970s, development had its objectives considerably broadened by the inclusion of poverty alleviation in its agenda. The movement from a single to a multiple development objectives included variants of distribution oriented strategies and remained with the reliance on the state in providing minimal requirements to citizens, from basic needs to basic consumption. As the reliance of the State is minimized in the 1980s with the decrease of the Soviet Union influence over the globe, the trust on the state was substituted by the trust on markets.

During the 1990s until the current days, development theories are still struggling to find the proper mix between the degree of government intervention and the reliance on markets, while being accused of running out of big ideas (Trubeck \& Santos, 2009: 15). In development terms, all these transformations contributed to the idea embraced in the twenty-first century that development also evidences the idea of freedom, explained so wisely by Amartya Sen within the idea of 'Development as Freedom' (Sen, 2009), which means freedom of choice - and that is, also, the freedom that developing countries are still struggling to find in the WTO system. Coalitions maybe then a positive mechanism for these countries to follow and strengthen the goals and interests in the contemporary era. And according to Chimni, "not only historical but also contemporary experience tells us that free trade may be good in principle, but free trade policies need to be implemented gradually as an economy gathers strength and particular sectors become competitive' (Chimni, 2009: 25). There is thus a long way until free trade and liberalization practices can take place and thereby that Reciprocity can be thought seriously in order to, eventually, be fairly implemented.

\section{Conclusion}

In sum, the asymmetry observed between different stages of economic development reveals the potential difficulties in establishing equal obligations between countries through the role of Reciprocity. The responsibility of governing and ruling international relations inherit the visible obstacles to be faced by any single institution that would intend to address all the trading problems and offer them solutions beforehand. The law needs to adapt itself to the current transformations of a multi-polar world. The impasses in the current Doha Round might be useful in forcing new ideas to be brought and paradoxes to be resolved. The current challenge becomes to conciliate the SDT, Reciprocity and development concerns.

Empirical evidences testified the collapse of some of preferential systems implemented until the present, but mainly because those methods did not inherit the real meaning of preferences as they were supposed to. It shall be reminded that those preferences were rarely given on a non-reciprocal basis and usually beneficiary countries would have to promote structural reforms in their domestic policy or institutions as dictated from outside. At that time, it was quite rare that an advantage would be given to a developing country with no bargaining power in a 
benevolent act from rich countries. Consequently, the answer is not found in the return of Reciprocity within a mercantilist approach. Rather, the objectives have to be reallocated, considering the necessity of empowering weaker states. Transformations in order to be efficient towards the promotion of growth and in the direction of imbalances reduction, point out that States shall not have restrained their sovereignty. Instead, government intervention may be required in order to bring the desirable competition to many of national industries, while the SDT is needed to assist this process.

Considering the scope widening from the GATT 1947 to the WTO, it shall be noted that the pursuit of the free trade has to be synchronized with the promotion of higher levels of development within and between member states. The right path to be followed within WTO system is yet to be achieved, but the need for SDT is evident when equal rules are not supposed to apply to unequal situations. Therefore, developed countries need to go beyond the pursuit of self-interest aims in order to recognize that they also might be better off in a world with vigorous competition among contracting parties. Developing countries, for their turn, may look for more coalitions as a positive mechanism to follow and strengthen the goals and interests in the contemporary era.

All in all, international rules that neglect economic imbalances will not bring the necessary global welfare and, what is more, are condemned to fail the accomplishment of one of the main purposes of the WTO: the development itself. At the end, preferential systems do not go against liberalization. Instead, the SDT intends to graduate the liberalization process through fairness (development) and to enable, only afterwards, that seriously discussions regarding free trade and Reciprocity can be held regarding their full, or more plausibly, partial implementation.

\section{References}

Alavi, A. (2009). Legalization of Development in the WTO. Netherlands: Kluwer Law International BV.

Alessandrini, D. (2009). Making the WTO "More Supportive of Development"? The Doha Round and the Political Rationality of the WTO's Development Mission. Law, Social Justice \& Global Development Journal. Retrieved from http://www.go.warwick.ac.uk/elj/lgd/2009_1/alessandrini.

Alessandrini, D. (2011). Developing Countries and the Multilateral Regime. Oxford: Hart Publishing.

Carl, B. M. (2011). Trade and the Developing World in the $21^{\text {st }}$ Century. New York: Transnational Publishers Inc.

Chang, H. J. (2008). Bad Samaritans: the myth of free trade and the secret history of capitalism. New York: Bloomsbury Press.

Chimni, B. (2009). Developing Countries and the GATT/WTO System. In C. Thomas, \& J. P. Trachtman (Eds.), Developing Countries in the WTO Legal System. New York: Oxford University Press. http://dx.doi.org/10.1093/acprof:oso/9780195383614.003.0002

Costa Filho, J. R., \& Turola, F. (2013). Short-run inflow, long-run impacts (Unpublished paper).

Desse, D. (2008). World Trade Politics: Power principles and leadership. Routledge: New York.

Dunoff, J. L. (2009). Dysfunction, Diversion, and the Debate Over Preferences. In C. Thomas, \& J. P. Trachtman (Eds.), Developing Countries in the WTO Legal System. New York: Oxford University Press. http://dx.doi.org/10.1093/acprof:oso/9780195383614.003.0003

Evans, P. (1979). Dependent Development. New Jersey: Princeton University Press.

Griffin, K. (1978). International Inequality and National Poverty. London: Macmillan.

Harvey, D. (2005). A Brief History of Neoliberalism. New York: Oxford University Press.

Hudec, R. (1987). Developing Countries in the GATT Legal System. London: Aldershot.

Hunter, J. (2003). Broken Promises: Trade, Agriculture and Development in the WTO. Melbourne Journal of International Law, 4, 299-322.

Irish, M. (2010). Special and Differential Treatment, Trade and Sustainable Development. In Law and Development Institute Inaugural Conference. Sydney, Australia.

Ismail, F. (2012). Is the Doha Round dead? What is the way forward? BWPI Working Paper, (167).

Krippner, G. (2005). The financialization of the American economy. Socio-Economic Review, 3, 173-208. http://dx.doi.org/10.1093/SER/mwi008

Leahy, J. (2013). Brazil, the first big 'soft' power. FT Magazine, Febr 23rd, 24th. 54pp. 
Lundberg, E. L. (2010). Bancos Oficiais e Credito Direcionado: o que diferencia o mercado de credito brasileiro? Relatório de Economia Bancaria e Credito 2010 (Banco Central do Brasil, Brasilia), 41. Retrieved from $\mathrm{http} / / / \mathrm{www}$. abbc.org.br/arquivos/rebc_2010.pdf

Mantega, G. (2009). Speech. Retrieved from http://www.fazenda.gov.br/audio/2009/outubro/a191009.asp

Moore, R. E. (1992). The level of development and GSP Treatment. Journal of World Trade, 26(6), 19-30.

Narlikar, A. (n. d.). Bargaining over the Doha Development Agenda: Coalitions in the World Trade Organization. Serie LATN Papers (34).

Ozden, O., \& Reinhardt, E. (2005) The perversity of preferences: GSP and developing country trade policies, 1976-2000. Journal of Development Economics, 78, 1-21. http://dx.doi.org/10.1016/j.jdeveco.2004.08.007

Piccioto, S. (1998) Linkages in International Investment Regulation: The Antinomies of the Draft Multilateral Agreement on Investments. University of Pennsylvania Journal of International Economic Law, 19(3), 731-768.

Rathborne, J. P. (2013). Brazil, the first big 'soft' power. FT Magazine, Feb 23rd, 24th. (28-30).

Rodrik, D. (2011). The Globalization Paradox. New York: WW Norton \& Company.

Sen, A. (2009). Development as Freedom. Anchor Books: New York.

Steger, D. (2007). The Culture of WTO: Why it Needs to Change. Journal of International Economic Law, 10(3), 483-491. http://dx.doi.org/10.1093/jiel/jgm020

Steinberg, R. (2002). In the Shadow of Law or Power? Consensus-Based Bargaining and Outcomes in the GATT/WTO. International Organization, 56(2), 339-374. http://dx.doi.org/10.1162/002081802320005504

Stiglitz, J. E., \& Charlton, A. (2005). Fair Trade For All. New York: Oxford University Press.

Survival of the quickest: Frequent crisis have made for strong banks and nimble financiers [A Special Report on business and finance in Brazil]. The Economist, (2009, November 14), 6.

Thomas, C., \& Trachtman, J. P. (2009). In C. Thomas, \& J. P. Trachtman (Eds.), Developing Countries in the WTO Legal System (pp. 1-21). Oxford University Press, New York. http://dx.doi.org/10.1093/acprof:oso/9780195383614.003.0001

Trebilcock, M. J., \& Howse, R. (2005). The Regulation of International Trade (3rd ed., pp759). New York: Routledge.

Trubek, D. M., \& Cottrel, P. M. (2009). Robert Hudec and the Theory of International Economic Law: The Law of Global Space. In T. Chantal, \& J. P. Trachtman (Eds.), Developing Countries in the WTO Legal System. New York: Oxford University Press. http://dx.doi.org/10.1093/acprof:oso/9780195383614.003.0007

WTO. (2001, October 22). Declaration by the Group of 77 and China on the Fourth WTO Ministerial Conference at Doha, Qatar.

WTO. (1947, October 30). GATT 1947. Retrieved from http://www.wto.org/english/docs_e/legal_e/gatt47_01_e.htm

WTO. (1979, November 28). Decision on Differential and More Favourable Treatment Reciprocity and Fuller Participation of Developing Countries (L/4903). Retrieved from http://www.wto.org/english/docs_e/legal_e/enabling_e.pdf

WTO. (1979, November 28). Declaration on Trade Measures Taken for Balance-of-Payments Purposes. BISD 26S/205, 208. Retrieved from http://www.wto.org/english/docs_e/legal_e/tokyo_bop_e.pdf

WTO. (1994, April 15). GATT 1994. Retrieved from http://www.wto.org/english/docs_e/legal_e/06-gatt_e.htm

WTO. (1994, April 15). Marrakesh Agreement Establishing the World Trade Organization. Retrieved from http://www.wto.org/english/docs_e/legal_e/04-wto_e.htm

WTO. (2001). Preparations for the Fourth Session of the Ministerial Conference: Proposal for a Framework Agreement on Special and Differential Treatment. Presented by Cuba, Dominican Republic, Honduras, India, Indonesia, Kenya, Malaysia, Pakistan, Sri Lanka, Tanzania, Uganda and Zimbabwe, WTO Doc $\mathrm{WT} / \mathrm{GC} / \mathrm{W} / 442$.

WTO. (2002, December 9). European Communities - Conditions of Tariff Preferences to Developing Countries: Request for the Establishment of a Panel by India. WT/DS246/4. Retrieved from http://www.wto.org/english/tratop_e/dispu_e/cases_e/ds246_e.htm 
$\begin{array}{lll}\text { WTO. Agreement } & \text { on } & \text { Trade-Related } \\ \text { http://www.wto.org/english/docs e/legal e/18-trims.pdf }\end{array}$

Measures. $\quad$ Retrieved from

WTO. Settling Disputes. Retrieved from http://www.wto.org/english/thewto_e/whatis_e/tif_e/disp1_e.htm

WTO. Who are de developing countries in the WTO? Retrieved from http://www.wto.org/english/tratop_e/devel_e/d1who_e.htm

\section{Copyrights}

Copyright for this article is retained by the author(s), with first publication rights granted to the journal.

This is an open-access article distributed under the terms and conditions of the Creative Commons Attribution license (http://creativecommons.org/licenses/by/3.0/). 